\title{
Impact of Water Availability on Land and Water Productivity: A Temporal and Spatial Analysis of the Case Study Region Khorezm, Uzbekistan
}

\author{
Maksud Bekchanov ${ }^{1}{ }^{*}$, Aziz Karimov ${ }^{1}$ and John P. A. Lamers ${ }^{2}$ \\ 1 Center for Development Research (ZEF), Bonn University, D-53113 Bonn, Germany; \\ E-Mail: akarimov@uni-bonn.de \\ 2 ZEF/UNESCO (Khorezm) project, Urgench State University, 220100 Urgench, Uzbekistan; \\ E-Mail: j.lamers@zef.uzpak.uz \\ * Author to whom correspondence should be addressed; E-Mail: maksud@ uni-bonn.de; \\ Tel.: +49-(0)-228-73-4962; Fax: +49-(0)-228-73-1889.
}

Received: 10 August 2010; in revised form: 3 September 2010 / Accepted: 15 September 2010 / Published: 19 September 2010

\begin{abstract}
Since irrigation water is assumedly the predominant factor determining crop yield, the difference in irrigation water availability across the administrative sub-districts of the Khorezm region, Central Asia, also inflicts an unequal distribution of agricultural revenues. Considering the national aim of a fair distribution and efficient use of resources, here we analyze the relationships between irrigation water access and rural welfare from 2000 to 2007 by descriptive statistics. Analyses revealed not only the general dependency of agricultural revenue on irrigation water availability, but also occurrence of low land productivity during water scarce years and, irrespective of the annual water availability, in some tail end regions each year. Furthermore, apart from irrigation water availability, land productivity was also impacted by soil quality, cropping structure, and type of land ownership. Fair distribution of water and land resources should also take into consideration population density. It is argued that an anticipated equal and efficient water allocation necessitates improved irrigation water conveyance, distribution, and application efficiency via best water management practices. Liberalization of markets, development of a market infrastructure and improvement in yields also contribute to increased land and water productivity.
\end{abstract}

Keywords: fair resource distribution; privatization; water allocation; efficiency; liberalization 


\section{Introduction}

Sustainability, equity and resource use efficiency in water use planning and policy are main pillars of an Integrated Water Resources Management (IWRM) paradigm [1]. Global Water Partnership [2] defined IWRM as a "process of coordinating development and management of water, land and related resources for maximizing of economic results and social welfare equitably with no compromise on sustainability of environment". When introducing IWRM concepts, a fair distribution of irrigation water is of particular interest in those areas characterized by frequent disruptions to reliable water access. Since distance to the main water source recurrently inflicts different levels of water availability for the water user, consequently crop yields and agricultural revenues are affected. The complexity of the linkages between agricultural revenue and water availability are well-illustrated in the Khorezm region in arid Central Asia, located in the northwest of Uzbekistan at the tail end of the Amu Darya River.

Irrigated agriculture plays a dominant role in the economy of Uzbekistan in general and in the study region Khorezm in particular. Both on national and regional levels, more than $90 \%$ of all water resources are used by the agricultural sector [3,4]. Starting in 1960s, a vast irrigation network was constructed in the Khorezm region to service croplands. Recent research findings, however, illustrated that the irrigation network efficiency does not exceed 60\% [5], and improvements both at the field and system levels are in high demand. Additionally, water deficiencies at the tail ends of the irrigation network, even in years of abundant water supply, are caused by badly managed water distribution, which aggravates the problem of water supply to producers. Frequently occurring water shortages and increased prices for other production factors such as fertilizer and fuel in the last years, in combination with disproportional increase in farm output prices, call for increasing water productivity and innovative water use efficiency. Owing to the inverse relationship between water use improvement potential and financial feasibility of various water-wise options, meaning that water-efficient technologies are usually more capital intensive [6], an improved understanding of key factors impacting land and water productivity are imperative for a better informed decision making.

In the aftermath of independence from the former Soviet Union in 1991, Uzbekistan initiated several reforms including market liberalization, land privatization and the introduction of participatory approaches to water distribution [7]. Although various changes are visible in the agricultural and irrigation water management sectors (e.g., the emergence of private farmers and appearance of water users associations), much still needs to be done. For instance, the newly established structures for the distribution and management of irrigation water do not currently permit a fair water distribution among water users. This is partly due to differences in location along the waterway and varying degrees of power between upstream elites with good relationships to water managers and off-stream inhabitants with less assets and connections [7]. Müller [8] analyzed the intra-regional crop water allocation in the study region Khorezm and concluded that tail end users constantly have to cope with increased water losses and, in turn, lower water availability, compared to head end users and areas close to the water source. Conrad's [9] findings also indicated high water losses in water conveyance to off-stream districts, which in turn decreased water availability at field level for tail end users. However, linkages between water availability and agricultural output value in Central Asia have as yet received little attention. Abdullaev et al. [7] analyzed the relationship between the remoteness from water 
sources and living standards at the grassroots level based on selected water users associations (WUA) located at different distances from water sources. However, the inter-district agricultural revenue differentiations caused by irrigation water availability should be of particular interest to national and regional policymakers striving for equitable access to and efficient use of water resources. Considering the importance of the relationship between water access and agricultural production, this study uses descriptive statistical tools, such as mean, variance and variation coefficient (VC), to analyze the dependency of land and water productivity on the availability of irrigation water. The study hypothesizes that not only the temporal and spatial distribution of irrigation water has a significant impact on the agricultural output in the case study region Khorezm but also institutional, organizational and economic factors. Finally, suggestions for improving water productivity are discussed with regards to meeting food demands under sustainable cultivation practices, such as crop diversity, while developing infrastructure and liberalizing agricultural commodity markets.

\section{Materials and Methods}

\subsection{Description of the Study Region}

The analyses were conducted for the Khorezm region in Northwest Uzbekistan. As part of the Lower Reaches of the Amu Darya lowlands, it is located between 60.05 and $61.39 \mathrm{~N}$ and 41.13 and $42.02 \mathrm{E}$. The distance from the present Aral Sea shore is about $250 \mathrm{~km}$. The territory stretches $280 \mathrm{~km}$ from the Northwest to Southeast and covers $6,052 \mathrm{~km}^{2}$.

The Khorezm region borders with the Karakum and Kyzylkum deserts which determine the severely arid continental climate characterized by short cold winters, with temperatures falling as low as $-20{ }^{\circ} \mathrm{C}$, followed by long, hot and dry summers, with temperatures reaching $+45^{\circ} \mathrm{C}$ [10]. Annually, 200 days are free of frost. The annual precipitation $(80-120 \mathrm{~mm})$ is far below the annual evaporation $(1,200 \mathrm{~mm})$, which necessitates irrigation for crop production. About $40 \%$ of the precipitation falls in spring, $20-25 \%$ in the fall, and only $10 \%$ during the summer months. Precipitation has little influence on the growth and development of agricultural crops [9].

Despite being a rather small area (about $1.5 \%$ of the total area of Uzbekistan), the share of the population in Khorezm with 1.506 million inhabitants (as of 2007) is more than 5\% of the total population of Uzbekistan. About three quarters of the population is rural. Although the World Food Program [11] noted the threshold value of poverty in Central Asia at $\$ 2.15$ per person per day, the $\$ 1$ per day poverty threshold line has been frequently used for comparison and according to the latter threshold, slightly less than $30 \%$ lives below the poverty line [12].

\subsection{Cropland Allocation, Regional Population and Agricultural Commodity Prices}

Secondary data from various sources from the years 2000 through 2007 were used during analyses. Demographic data as well as datasets on cropland allocation and production across the administrative districts were provided by the Regional Statistical Department of the Khorezm Region (OblStat). Since this Department usually elaborates data on the basis of farmers' individual annual reports on land use and crop production levels as well as on the basis of the reports of local administrations, it is the sole and most reliable database. 
Agriculture is the centerpiece of Khorezm's economy, as evidenced by its $46 \%$ contribution to the Gross Regional Product (GRP) [13] in which raw cotton, wheat and horticultural production have a major share [14]. Moreover, agriculture is the main source of foreign hard currency, contributes to the development of industry and the service sector of the economy, and enhances food security. As a result of the high demand for agricultural commodities and triggered by the cotton self-sufficiency policy of the former Soviet Union era, the irrigated areas in Khorezm increased steadily from 200,000 ha in 1982 to 276,000 ha in 1999 until the drought periods of 2000 and 2001 (Figure 1). Owing to these drought spells, as compared to 1999, the cropped land area decreased by $4 \%$ in 2000 and by $6 \%$ in 2001. The annual irrigated area has stabilized around 265,000 ha since 2001/2002.

Figure 1. Dynamics of the irrigated area in Khorezm (1982-2006).

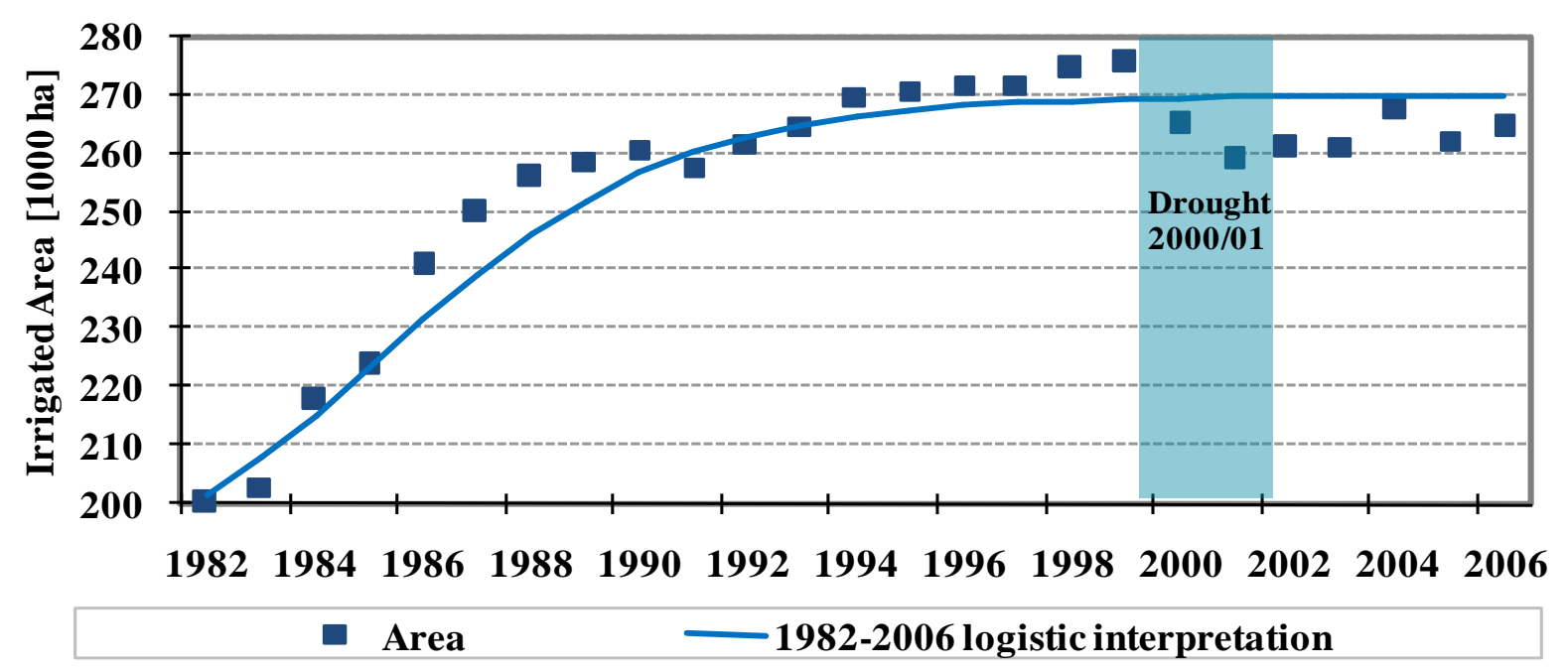

One force driving the gradual but steady increase of irrigated areas in the study region is a steady population growth (Figure 2). Whereas the total population increased by $50 \%$ between 1989 (1.014 million people) and 2007 (1.504 million people), the percentage of the rural population increased from $72.3 \%$ in 1989 to $78.2 \%$ in 2007 . The high share of the rural population underlines the importance of the agricultural sector for their livelihoods.

Figure 2. Population growth in the Khorezm region (1989-2007).

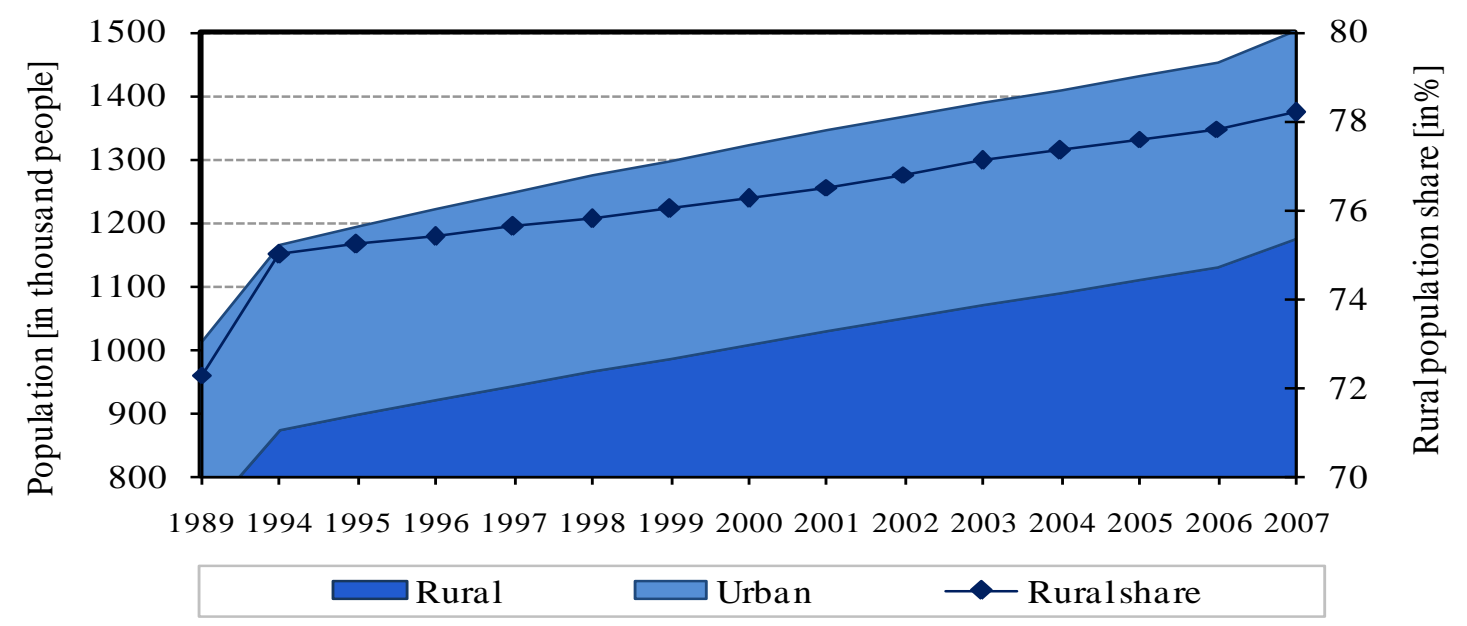


Cotton was a major crop in Khorezm during the Soviet era. But even following independence in 1991, cotton remained the dominant state order crop (winter wheat is the second strategic crop), which is cultivated annually on about 110,000 ha or $48 \%$ of the total irrigated land (Figure 3 ).

Figure 3. Crop land allocation in the Khorezm region (1991-2007).

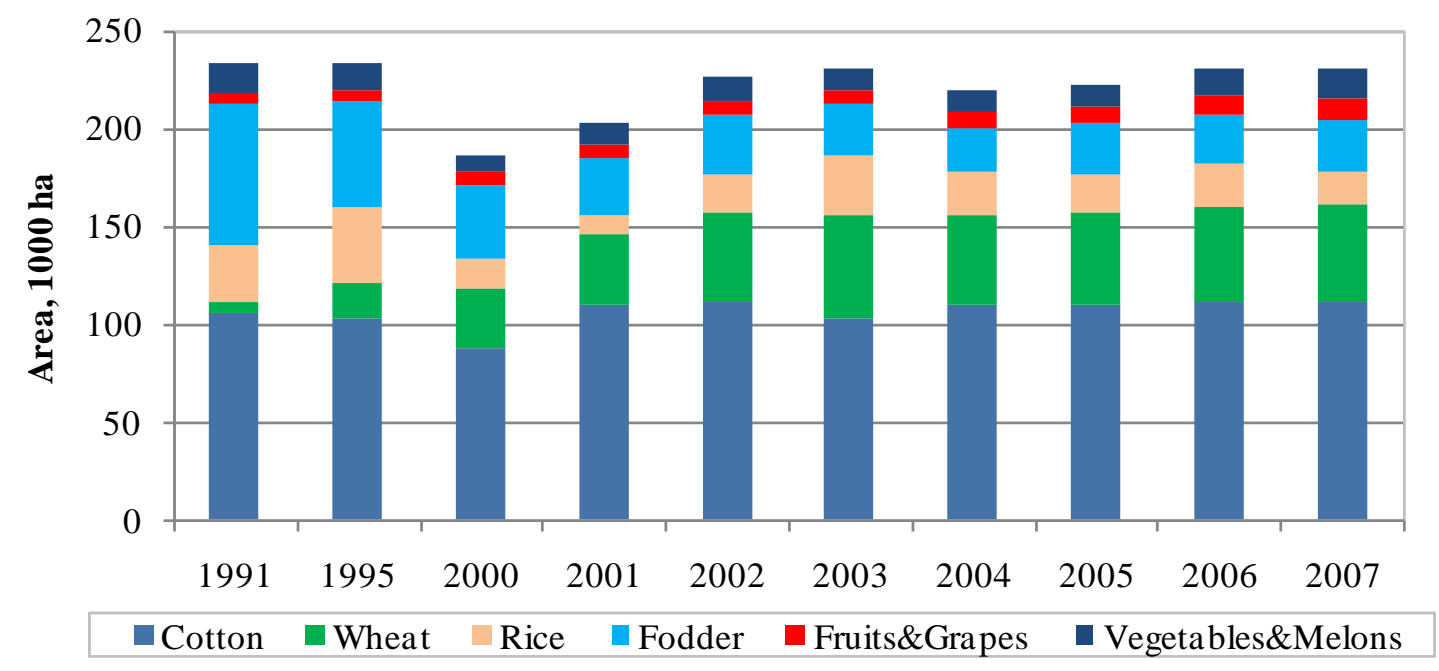

Export of the "cash crop" cotton, renders about 98\% of the total regional export revenues [13], thus contributing to the regional welfare via both the acquisition of hard currency and by the value added tax (VAT) generated during the domestic processing of raw cotton and fiber [15]. Consequently, as a state order crop, cotton production is under strong scrutiny from the government, which regulates the cropped area for cotton production and determines the prices for inputs and raw cotton. In exchange, the government supports cotton producers with input subsidies to lower the expenses for fertilizers, chemicals and fuel, as well as by providing low interest rates for bank credits [15].

The second major crop, winter wheat, covers on average $20 \%$ or 45,000 ha of the total cropped area annually. Until independence in 1991, very little wheat was produced on the irrigated areas in the region because the domestic demand was satisfied via imports from other Soviet republics [15]. Following independence, wheat production became part of the crop rotation within the irrigated areas so as to reduce dependency on wheat imports and lay the basis for domestic food security. Consequently, the share and area of wheat-cropped lands has been increased annually while the area for fodder crops particularly has been substantially decreased. Winter wheat is mainly cultivated in rotation with cotton or rice and after harvest in July followed by vegetables, fodder maize or short-duration rice.

Furthermore, the downstream districts of the Amu Darya River, such as Khorezm, and the autonomous Republic Karakalpakstan, are the main rice producers in Uzbekistan. For instance, the Khorezm region provided 53\% of the national rice production although in 2007 rice was cropped only on $32 \%$ of the entire rice cropped area in the country [16,17]. In spite of increased stress over water and the high water demand of the paddy rice production in these tail-end regions, main incentives to maintain rice growing are the flatness of the fields, the intensive salt leaching that occurs due to the large amounts of water used during rice cultivation, and the free market with a substantial internal demand. Fodder crops such as clover, maize and others, also occupy a significant area (in average $12 \%$ after 2000) of the arable land although they are cultivated mainly in small household 
plots or Dekhkan (kitchen garden farmers) enterprises. The share of the areas cropped to vegetables and fruits are on average $3.7 \%$ and $3.0 \%$, respectively.

Despite these generalizations, cropland allocation differs across the administrative districts of the region (Figure 4). For instance, the highest share of cotton was observed in the Yangibazar district $(50.6 \%)$ while the lowest share was found in the Urgench district $(43.1 \%)$. The highest share of rice is found in Gurlen (17.6\%) and Khazarasp (14.3\%), due to their direct access to river water (Figure 7). Downstream districts such as Khiva and Kushkupir cropped rice only on $4.2 \%$ of their territory.

Figure 4. Cropland allocation across administrative districts, 2000-2007 average. (CTN-Cotton; GRN_-Grain; RIC_-Rice; FDR_Fodder; FRT_Fruit and Vegetables; $\mathrm{OTH}$ - other crops).

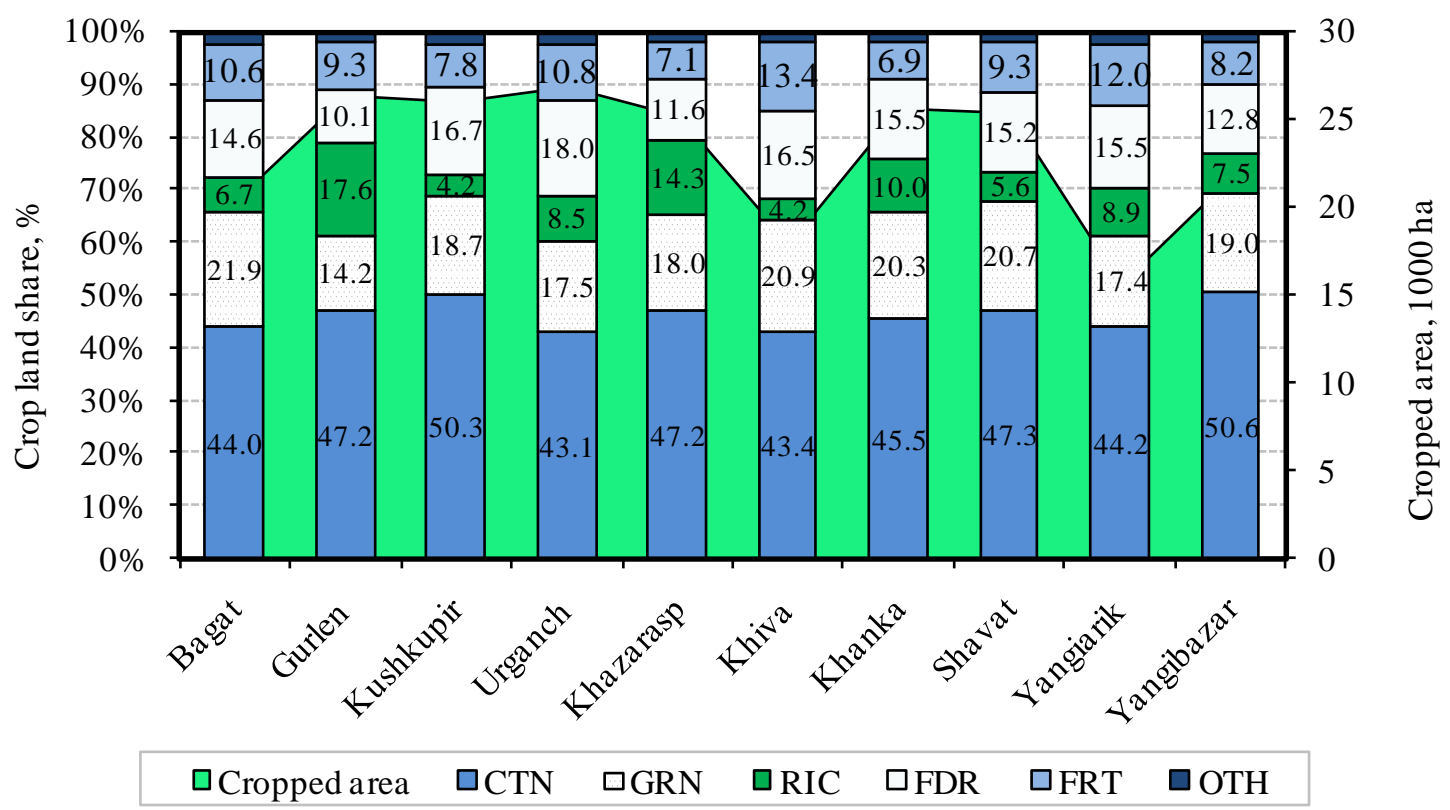

Agricultural commodity prices were evaluated based on weekly conducted market surveys in Urgench and Khiva dekhkan markets during six years. Constant prices from 2007 were applied in this study to estimate agricultural revenue. The official exchange rate used for the US\$ 1 was about UZS 1,500.

\subsection{Land Privatization}

Since the dissolution of the former Soviet Union, various privatization and market liberalization reforms have been taking place in the agriculture and irrigation sector in Uzbekistan, as was the case in other post-Soviet countries [18]. In 1993, the former kolkhozes and sovkhozes were transformed into shirkats (joint stock companies) while maintaining state land ownership. However, the entire production process and organization differed only slightly from the inherited ones [19]. An exception was made for the so-called tomorqas, which are about 0.23 ha in size and allocated to rural households within the boundaries of a shirkat. These household plots provided workers with an opportunity to crop vegetables, other staples and fodder [20]. Following privatization, the total number of livestock 
kept by households nearly doubled and currently accounts for about $92 \%$ of the total regional livestock resources, although it takes place on only $15 \%$ of the total cropped area [13].

Large-scale privatization imposed after 1998 sparked the emergence of private farms which operate on an area larger than 10 ha, yet under a land lease contract from the government, spanning a minimum of 50 years. However, shirkats retained the largest cropping areas and hence supplied the main share of the two state target crops - cotton and wheat - until 2004. On the basis of a Presidential Decree issued on March 3, 2000, shirkats were almost fully transformed into private farms and, towards the end of $2006,81 \%$ of the area was cropped by private farms while only $2 \%$ of the area remained allotted to state farms (Figure 5).

Figure 5. Change in the share of different entity types in total cropped land (in \%) over time in the Khorezm region.

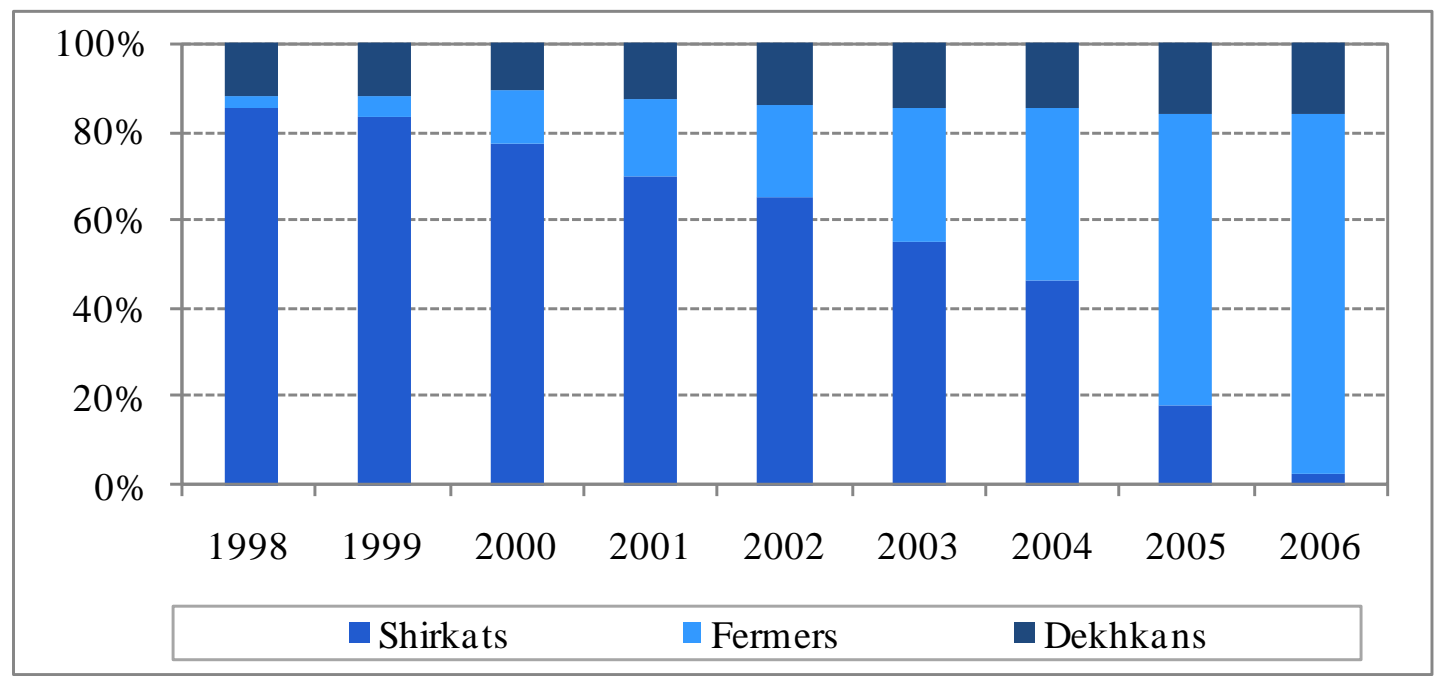

\subsection{Irrigation Water Use}

Data on irrigation water use in the leaching and vegetation periods was provided by the Khorezm Regional Branch of the Ministry of Agriculture and Water Resources Management (OblSelVodKhoz). Representatives of this ministry conduct daily measurements in each canal, and are therefore the sole source of complete and consistent data on irrigation water use and distribution [21].

The water supply for irrigation needs originates from the lower Amu Darya, which is collected in the Tuyamuyun reservoir and released during the vegetation period. The total annual water intake from the Amu Darya for irrigation and leaching purposes amounts to approximately $4.5 \mathrm{~km}^{3}$ in water abundant years (Figure 6).

Nearly one fourth of the total water intake is annually used for leaching that takes place in late winter and early spring as a pre-sowing activity to wash salts out of the topsoil layers. About $3.3 \mathrm{~km}^{3}$ is used during the vegetation period. The lowest water intake was observed in $2000\left(3 \mathrm{~km}^{3}\right)$ and $2001\left(2.2 \mathrm{~km}^{3}\right)$ within a 50-year record of water supply. Water intake in 2007 was moderate. Other years observed can be defined as water abundant years, meaning sufficient to provide irrigation water during the vegetation season to the estimated 260,000 ha of potential cropland. 
Figure 6. Annual water intake from the Amu Darya for irrigation and leaching, 2000-2007.

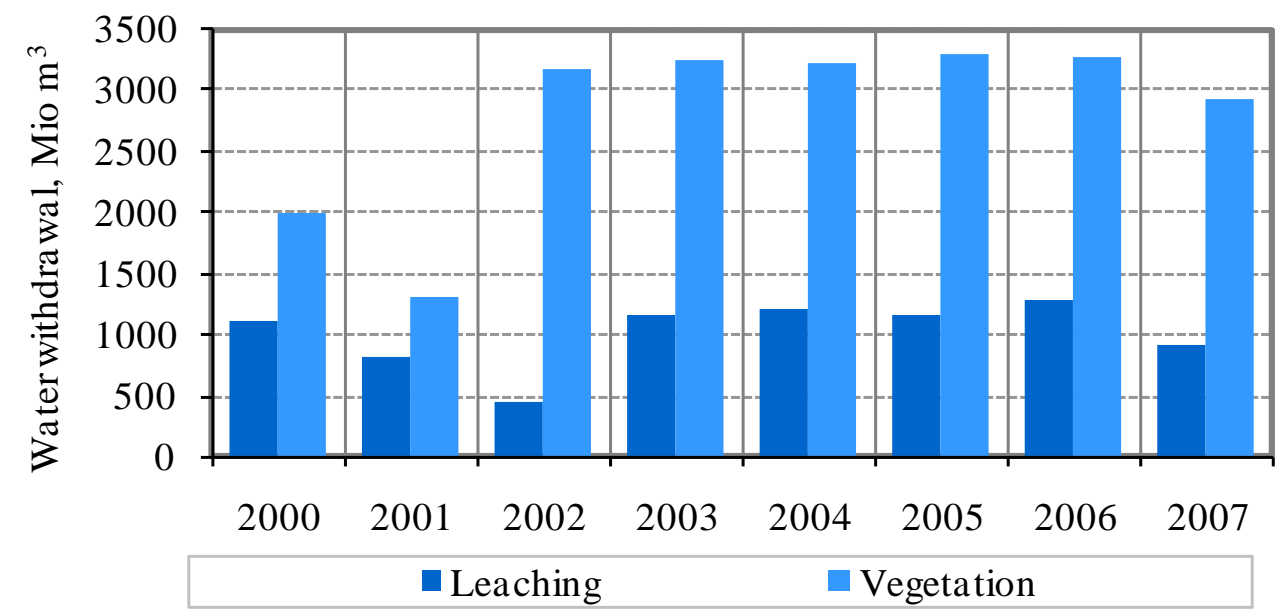

Water from the Amu Darya River is conveyed to the agricultural fields through a hierarchical network of magistral, inter-farm and on-farm canals. Magistral canals convey water through different districts from the river to inter-farm canals that transport water to the boundary of WUAs. On-farm canals are intermediaries between inter-farm canals and field level networks [22].

The irrigation water distribution system is based only partly on hydrological boundaries of water management, which in 2003 replaced the former solely administrative-territorial system of irrigation management [22]. In spite of this change on the water management level, official data on agricultural production (and in fact many other parameters) is still collected on administrative boundary level. As we used datasets covering the years 2000 through 2007 and covered the period when this change occurred, the spatial dimension of this analysis could focus only at administrative districts rather than hydrological boundaries.

\subsection{Water and Land Productivity; Productivity Differentiation; and Water Access Assessment Methodology}

Water productivity analysis has been used to illustrate the yield or economic output obtained from the use of a unit of water [23]. In this study, economic water productivity level was calculated as the ratio of the total value of agricultural production (output) to water intake of each district and used as an analogous for water productivity throughout this paper. Total agricultural production value (revenue) was estimated by summing individual crop revenues. Revenues for each crop were calculated as crop price multiplied by crop production volumes. Revenues from the livestock sector, which is about 50\% of the overall agricultural sector production, were not included. Due to the high salinity level of drainage waters at the tail end zones, as well as their negative impact on crop yield, possible re-use of water that leaves the borders of the districts was not considered. Districts have been classified according to water productivity and water use per hectare to compare water use efficiencies in these districts.

To show land productivity and agricultural revenue distribution, per hectare and per capita agricultural revenue across districts and over the years was calculated. To estimate the differentiation of all aforementioned indicators around their average, variation coefficients (VC) were evaluated as a ratio of the standard deviation (SD) to the mean of the analyzed series. 
Water availability in each district was estimated stepwise. In a first step, the distances between the border of the WUAs and water intake (source) point of the primary canal that attached each WUA, were calculated using ArcView software following Conrad [9]. Next, the average distance of WUAs from the water intake point was calculated for each of the ten administrative districts (Figure 7). This allowed, in a subsequent step, the classification of the districts according to the average distances of their WUAs from the source point of the nearest main canal.

Figure 7. Water access levels and groups of administrative districts.

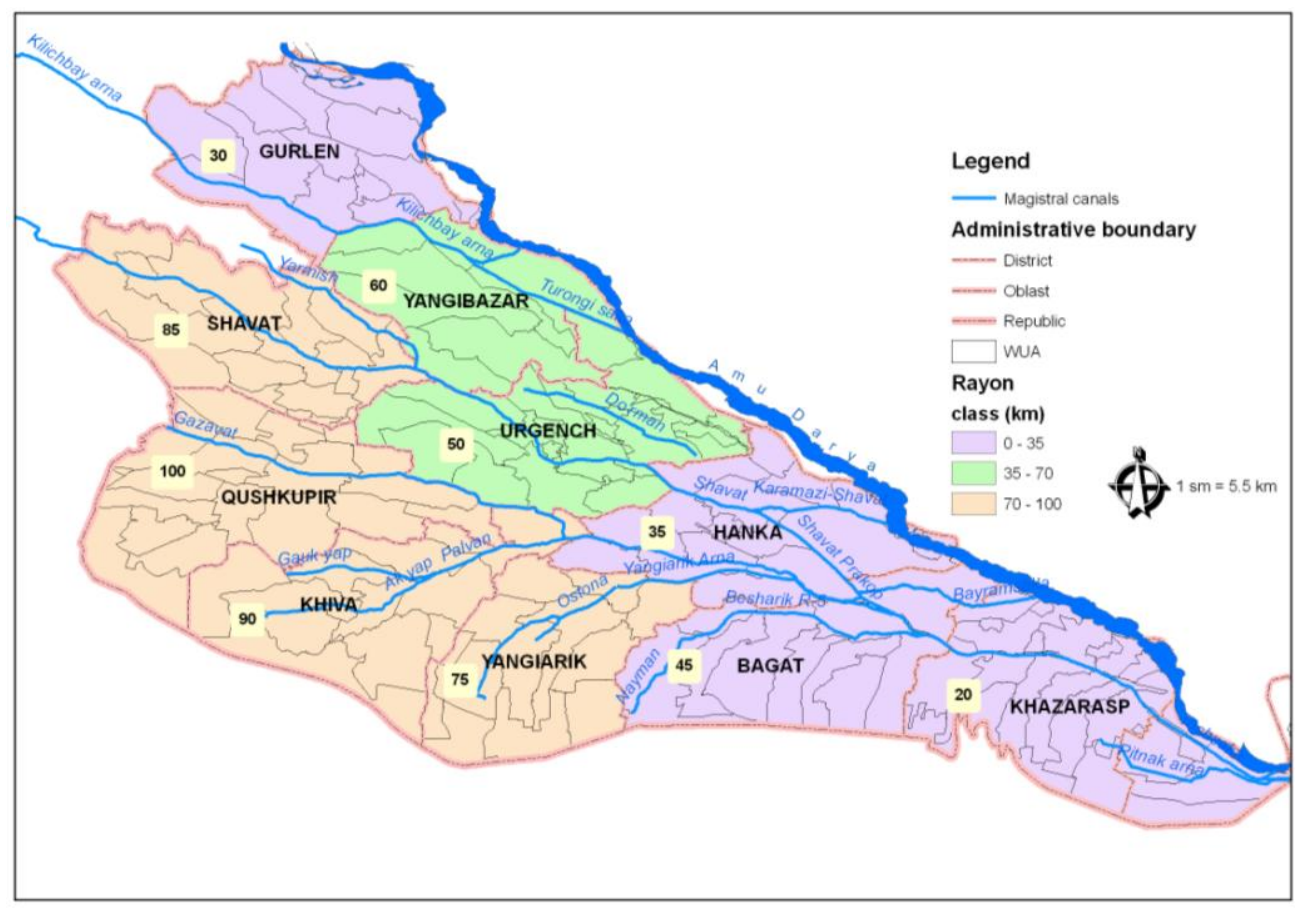

The estimations showed that the districts Kushkupir, Khiva, Shavat, and Yangiarik are tail-end users, whilst Urgench and Yangibazar districts were middle-end users. The other four districts (Khazarasp, Bagat, Khanka and Gurlen) were classified as upper-end users. Since this categorization of the administrative districts was based on the remoteness of each WUA from the source point of its main water delivery canal, the impacts of hydrological boundaries were effectively covered.

\section{Results and Discussion}

\subsection{Analysis of Land Productivity}

As a result of the differences in cropping structure and the differences in revenues from producing the different commodities, as well as the differences in water availability, total agricultural production value per hectare varied across the districts (Figure 8).

Downstream districts such as Khiva [2.45 Mio UZS (1,630 USD) ha ${ }^{-1}$ ] and Yangiarik [2.4 Mio UZS (1,600 USD) ha ${ }^{-1}$ ] had the highest per hectare revenue, which can be explained by a generally higher soil quality. However, also revenue differentiation in these districts over the observed years was substantially higher compared to those in other districts. Upstream districts such as Bagat [2.15 Mio UZS (1,430 USD) ha ${ }^{-1}$ ] and Gurlen [2.2 Mio UZS (1,466 USD) ha ${ }^{-1}$ ] obtained significantly 
higher agricultural revenue per hectare, whereas the lowest agricultural mean revenue per hectare was observed in the tail end district, Kushkupir due to water scarcity and consequent lowest yields.

Figure 8. Level and variation of agricultural output value across the districts, 2000-2007.

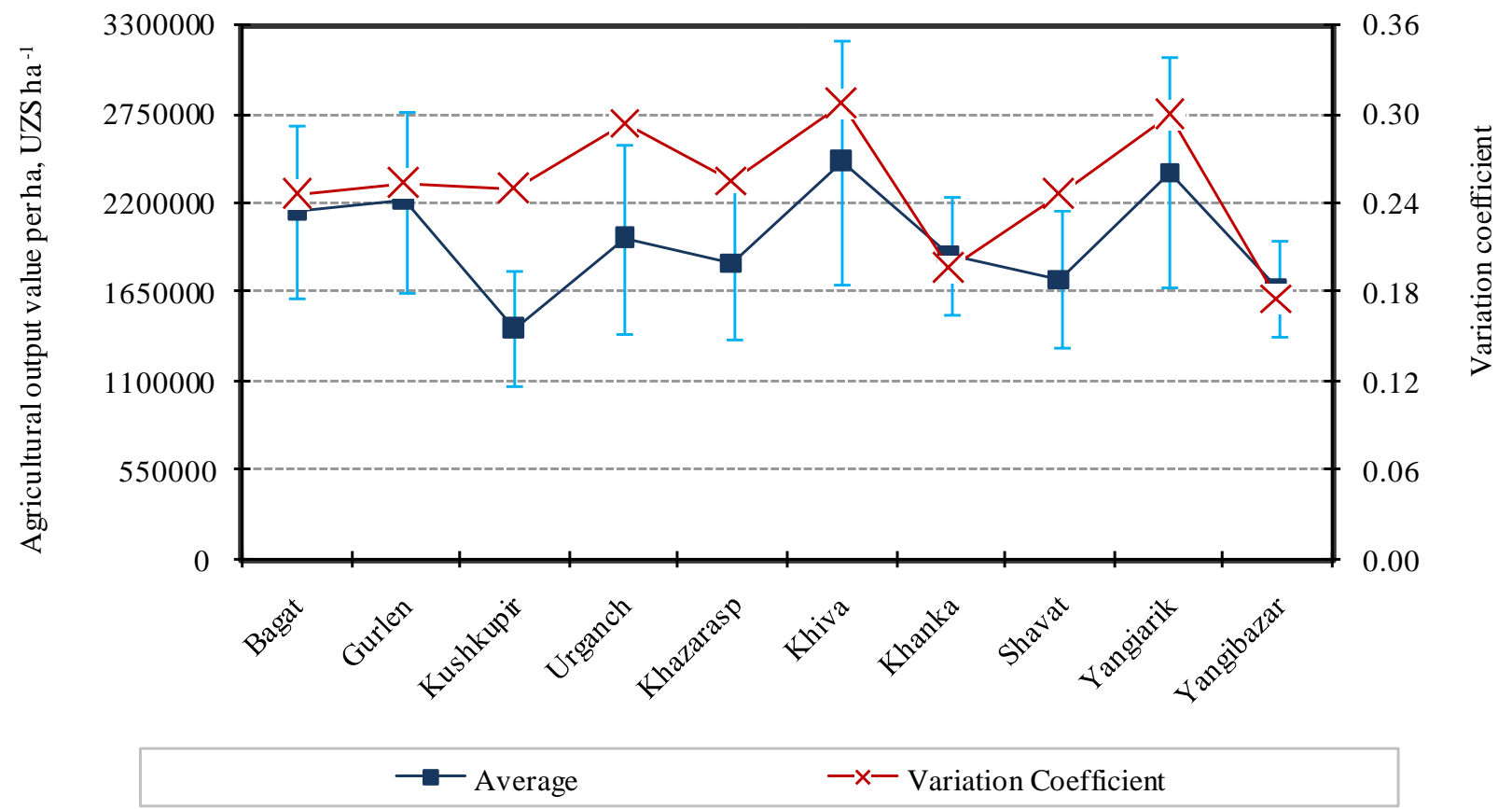

It seems that factors other than the proximity to the main canal, such as soil quality influencing on yield, closeness to regional markets [7] determining demand and consequent price levels, and differences in cropping patterns across the districts considering various prices for agricultural commodities, significantly impacted land productivity. However, one general trend seen across all locations is the close relationship between the level and variation of agricultural output value. The findings underlined that the districts with the lowest revenue per hectare had also more stable revenue per hectare, while the districts with higher land productivity experienced higher variations.

Agricultural output value per hectare tended to increase over the years observed (Figure 9), which may be partly explained by the nationwide liberalization reforms that partly allowed farmers to produce more marketable crops rather than being restricted only to produce the state order crops of cotton and winter wheat. The introduction of private farming following the dismantling of a state regulated large farm production in the former Soviet Union, has been accredited for an increased productivity in other countries with transition economies. It was consequently explained primarily by an increased feeling of ownership and, in turn, the desire to take care of the allotted cropland, as well as due to a sharp reduction in inefficient input use [18]. Although a similar effect has perhaps occurred following the transformation of the shirkats into private farm enterprises in Uzbekistan [20], the inclusion of the water scarce years - 2000 and 2001-illustrated in particular the substantial impact of water availability on land productivity. 
Figure 9. Level and variation of agricultural output value (UZS ha $\left.{ }^{-1}\right), 2000-2007$.

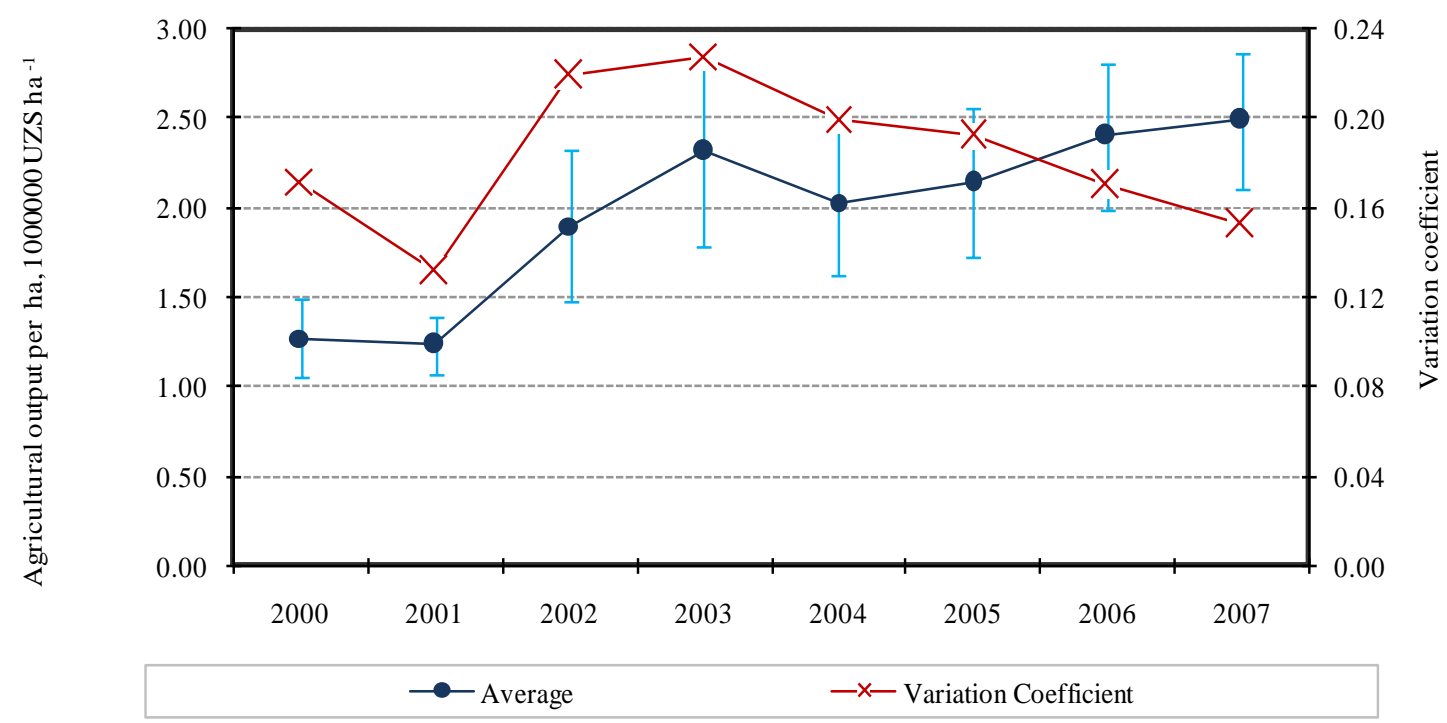

Temporal analysis of the agricultural output value per hectare showed high output variations in wet years compared to the low variations in dry years (Figure 9). For example, VC in 2001, a dry year, amounted to $13 \%$, but the VC averaged almost $20 \%$ between 2002 (wet) and 2006 (wet), and decreased to about $15 \%$ in 2007, a water normal year. The water scarce years 2000 and 2001, were characterized by more equitable, but less efficient land resources use, in contrast to the water abundant years that exposed less equitable, but more efficient land use.

\subsection{Irrigation Water Use and Productivity}

Water intake per hectare varied between 6,000 and 24,000 $\mathrm{m}^{3} \mathrm{ha}^{-1}$ (Figure 10). The downstream districts Yangiarik, Khiva and Kushkupir had the highest water use per hectare which was most likely due to the high water losses in conveyance and high share of water intensive crops, such as rice, cultivated in those districts. This confirms previous observations of Müller [8] who reported high water uses in downstream districts for the periods until 2001. One exception seemed to be the Shavat district. Despite being relatively far from the Amu Darya River, it is privileged by a direct water supply from one of the three primary irrigation canals in the region. The extreme high irrigation water use in the Bagat district, in spite of its relative proximity to the river, can be explained by the low water use efficiency throughout this district caused by the dominant (about 60\%) sandy and sandy loamy soil textures and, thus, the consequent high water infiltration rates and percolation losses (ZEF/UNESCO project findings).

The findings also demonstrated the reduced irrigation water use per hectare in water scarce years. For instance, water use in most of the districts in 2000 and 2001 was lower than $12,000 \mathrm{~m}^{3} \mathrm{ha}^{-1}$. However, when water abstraction increased, irrigation water use per hectare also increased to more than $18,000 \mathrm{~m}^{3} \mathrm{ha}^{-1}$ in most districts. The medium level of water use per hectare $\left(12,000-18,000 \mathrm{~m}^{3} \mathrm{ha}^{-1}\right)$ was solely specific to the cropping season in 2007. 
Figure 10. Water use per ha [in 1,000 $\mathrm{m}^{3} \mathrm{ha}^{-1}$ ] across the districts, 2000-2007.

\begin{tabular}{|c|c|c|c|c|c|c|c|c|c|c|}
\hline & 2000 & 2001 & 2002 & 2003 & 2004 & 2005 & 2006 & 2007 & Av. & SD \\
\hline Bagat & 9.3 & 6.8 & 15.5 & 22.2 & 18.7 & 18.8 & 20.1 & 15.6 & 15.9 & 0.34 \\
\hline Gurlen & 13.6 & 8.4 & 19.6 & 21.5 & 19.2 & 17.2 & 16.4 & 14.1 & 16.3 & 0.26 \\
\hline Kushkupir & 13.3 & 8.4 & 19.7 & 21.4 & 20.6 & 20.5 & 20.8 & 17.5 & 17.8 & 0.26 \\
\hline Urganch & 10.5 & 7.4 & 17.7 & 19.1 & 18.6 & 17.2 & 16.5 & 14.8 & 15.2 & 0.27 \\
\hline Khazarasp & 10.6 & 9.1 & 15.3 & 18.0 & 16.9 & 18.3 & 18.1 & 13.5 & 15.0 & 0.24 \\
\hline Khiva & 11.3 & 7.6 & 18.9 & 23.6 & 19.4 & 20.2 & 20.3 & 16.7 & 17.2 & 0.31 \\
\hline Khanka & 8.9 & 6.5 & 11.8 & 19.1 & 17.4 & 17.3 & 16.2 & 13.7 & 13.9 & 0.32 \\
\hline Shavat & 11.3 & 6.4 & 14.5 & 4 & 17.8 & 17.5 & 17.0 & 15.3 & 14.8 & 0.28 \\
\hline Yangiarik & 13.3 & 8.4 & 22.1 & 23.7 & 21.1 & 21.2 & 21.0 & 18.6 & 18.7 & 0.28 \\
\hline Yangibazar & 12.3 & 9.3 & 18.5 & 17.3 & 18.1 & 17.3 & 16.8 & 14.9 & 15.6 & 0.21 \\
\hline Average & 11.4 & 7.8 & 17.4 & 20.5 & 18.8 & 18.5 & 18.3 & 15.5 & & \\
\hline SD & 0.15 & 0.13 & 0.18 & 0.11 & 0.07 & 0.08 & 0.11 & 0.11 & & \\
\hline
\end{tabular}

Water productivity was influenced by temporal and spatial water availability (Figure 11). The lowest productivity overall was estimated for the furthest district Kushkupir, due to the combination of low yields and high water use per hectare. Due to lower yields, Yangibazar (in 2002 and 2004), Shavat (in 2004) and Yangiarik (in 2000) districts showed the lowest water productivity in certain years. At the same time, the upstream districts Bagat (in 2001), Gurlen (in 2006 and 2007), and Khanka (in 2007) attained water productivity levels of more than 175 UZS (0.12 USD) $\mathrm{m}^{-3}$ in some years.

Changes in overall water availability over the years impacted thus water productivity. Particularly in 2001 and 2007 when water extraction decreased significantly, higher water productivity levels [more than 135 UZS (0.09 USD) $\mathrm{m}^{-3}$ ] were observed. Previous assessments [24] showed the inverse relationship between water abundance and water productivity, which is in line with the present findings. It implies that farmers, water users, and water managers are capable of attaining higher water productivity under water scarce conditions without additional incentives [24].

Increased efficiency in conveyance, distribution, and application of water, particularly in districts such as Kushkupir, would also contribute to improving agricultural income distribution. Considering the high level of water losses in the irrigation network and during field applications, there is great potential to improve irrigation water use. Although, some advanced technologies are capital intensive, preventing risk averse farmers to adopt them, analyses showed they are economically efficient due to increased yields and several reduced costs compared to conventional methods of irrigation [6]. Moreover, liberalized markets, improved market infrastructure, and diversified crop production, would 
maintain higher agricultural revenue, thus entities would thrive from the higher water productivity $[20,22]$. Relaxing the state procurement system would provide more freedom to farmers in deciding what crops to grow. In this way, greater crop diversification and consequent higher agricultural revenue would be achieved [22]. However, crop diversification will be less effective without the development of a market infrastructure that supports farmers with extension services, financial services, and communication technologies, as well as initiatives to increase competitive advantages in the world market [20].

Figure 11. Water productivity [in UZS m ${ }^{-3}$ ], 2000-2007.

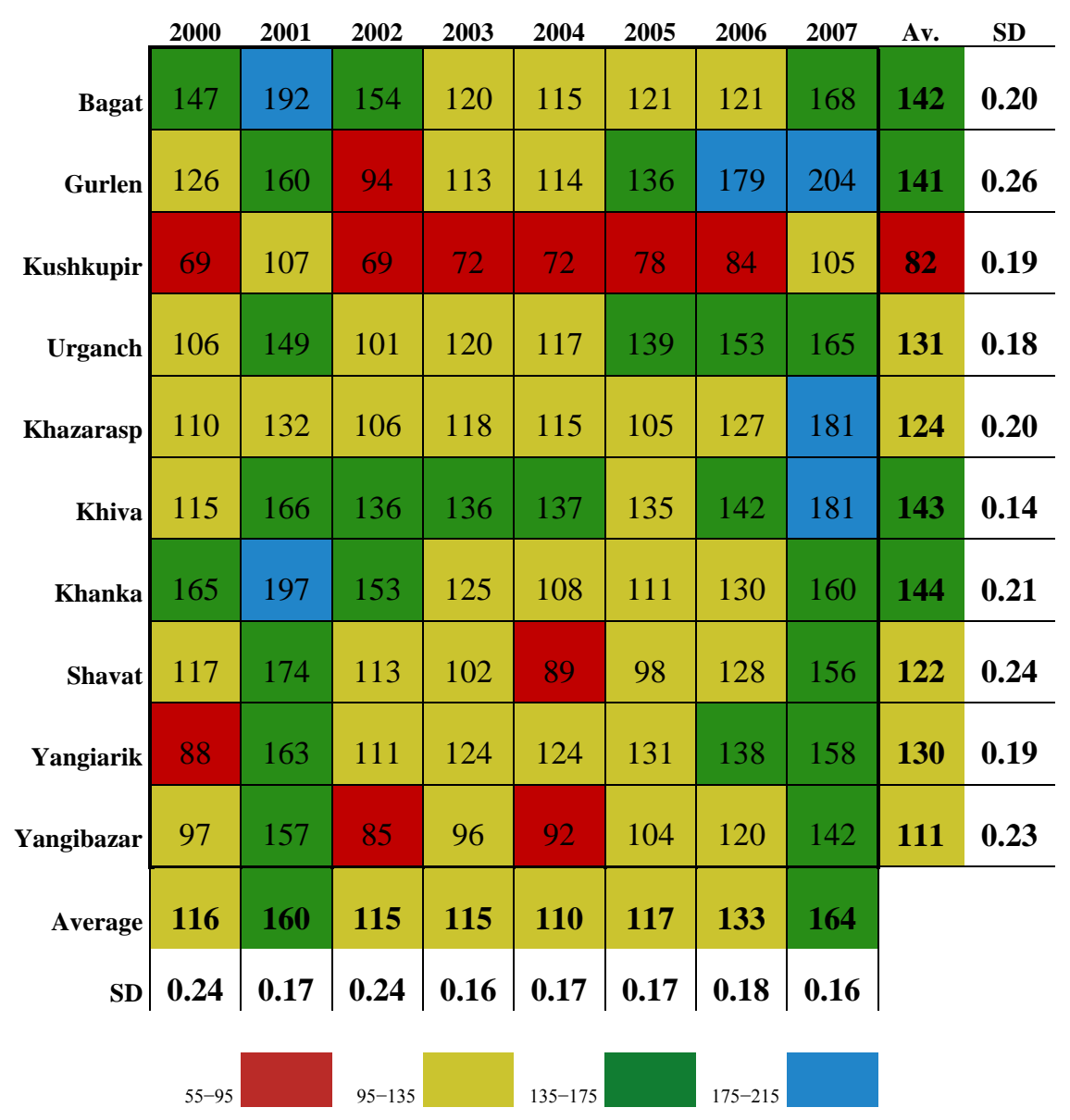

\subsection{Linkages between Water Availability and Income Differentiation}

The analyses of the per capita agricultural revenue differentiation across districts are particularly informative because they reveal the magnitude of the influence of the temporal and spatial water availability on rural livelihoods. Per capita agricultural revenue gradually increased from an average of 350,000 UZS (230 USD) in 2000 to on average 533,000 UZS (355 USD) in 2007 as a result of higher growth rates in agricultural output (Figure 12). However, a higher per capita agricultural revenue differentiation across the districts was observed in the years with the least water intake ( $\mathrm{VC}=0.31$ in 2001 and $\mathrm{VC}=0.36$ in 2007), which indicates an even greater vulnerability of tail end or densely populated districts during periods of water stress. Availing more area to marketable crops at the expense of the state order crops could decrease this per capita revenue variation. 
Figure 12. Temporal per capita agricultural revenue and its differentiation, 2000-2007.

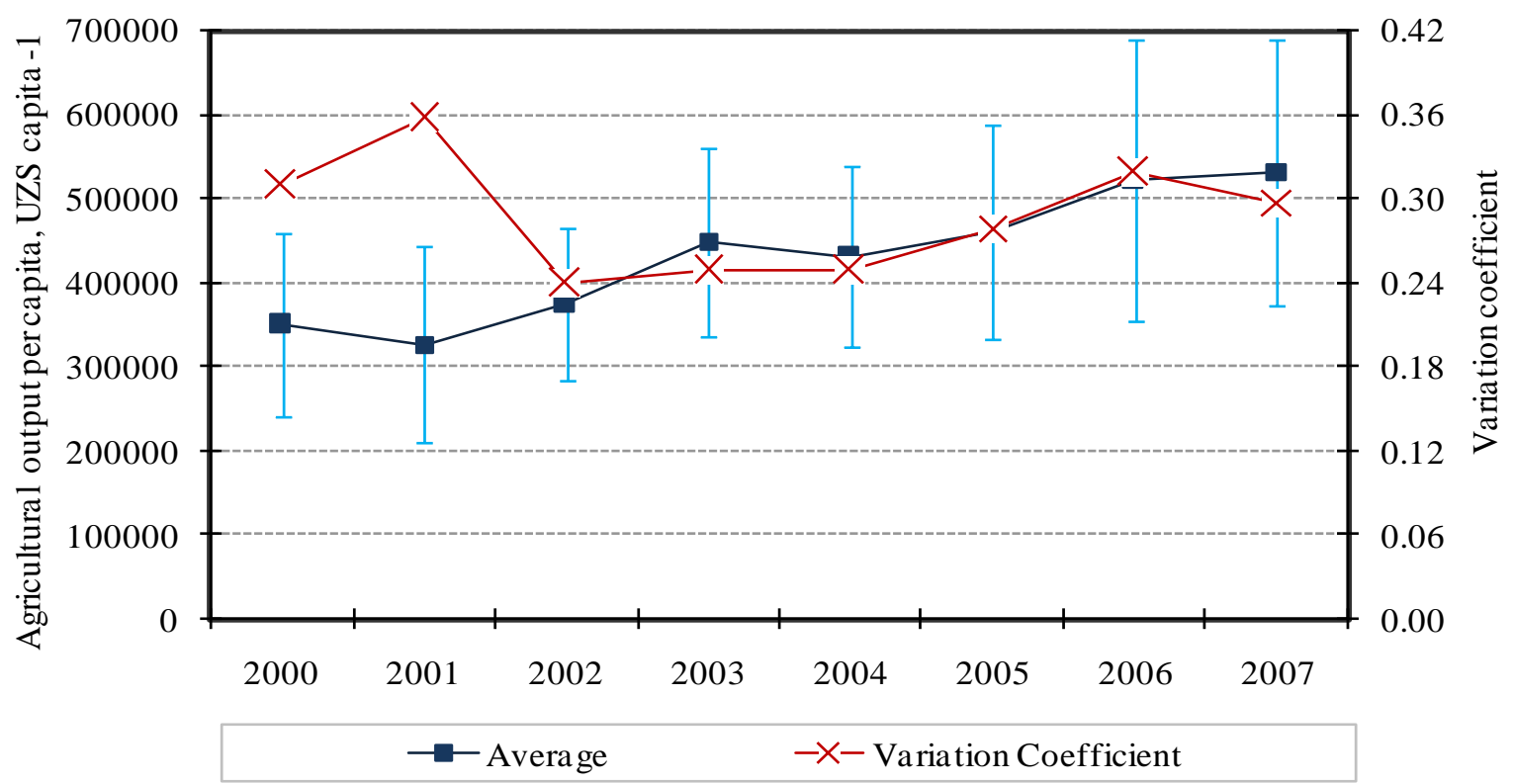

Spatial analysis also showed that downstream districts such as Kushkupir [334,000 UZS (223 USD) capita $^{-1}$ ] and Khiva [343,000 UZS (229 USD) capita ${ }^{-1}$ ] had lower agricultural revenue per capita (Figure 13). At the same time, Shavat (398,000 UZS (265 USD) capita ${ }^{-1}$ ) and Yangiarik [440,000 UZS (293 USD) capita $^{-1}$ ] had medium agricultural revenue per capita, but also showing higher variability as substantiated by a VC of $20 \%$ and $23 \%$, respectively. The highest agricultural revenue per capita was found in the least populated and most upstream districts such as Gurlen [646,000 UZS (430 USD) capita $^{-1}$ ] and Yangibazar [631,000 UZS (420 USD) capita ${ }^{-1}$ ]. Due to the dense population in Khazarasp, the per capita agricultural revenue in this district was the lowest [314,000 UZS (209 USD) capita ${ }^{-1}$ ].

Figure 13. Mean and variation in per capita agricultural revenue over districts, 2000-2007.

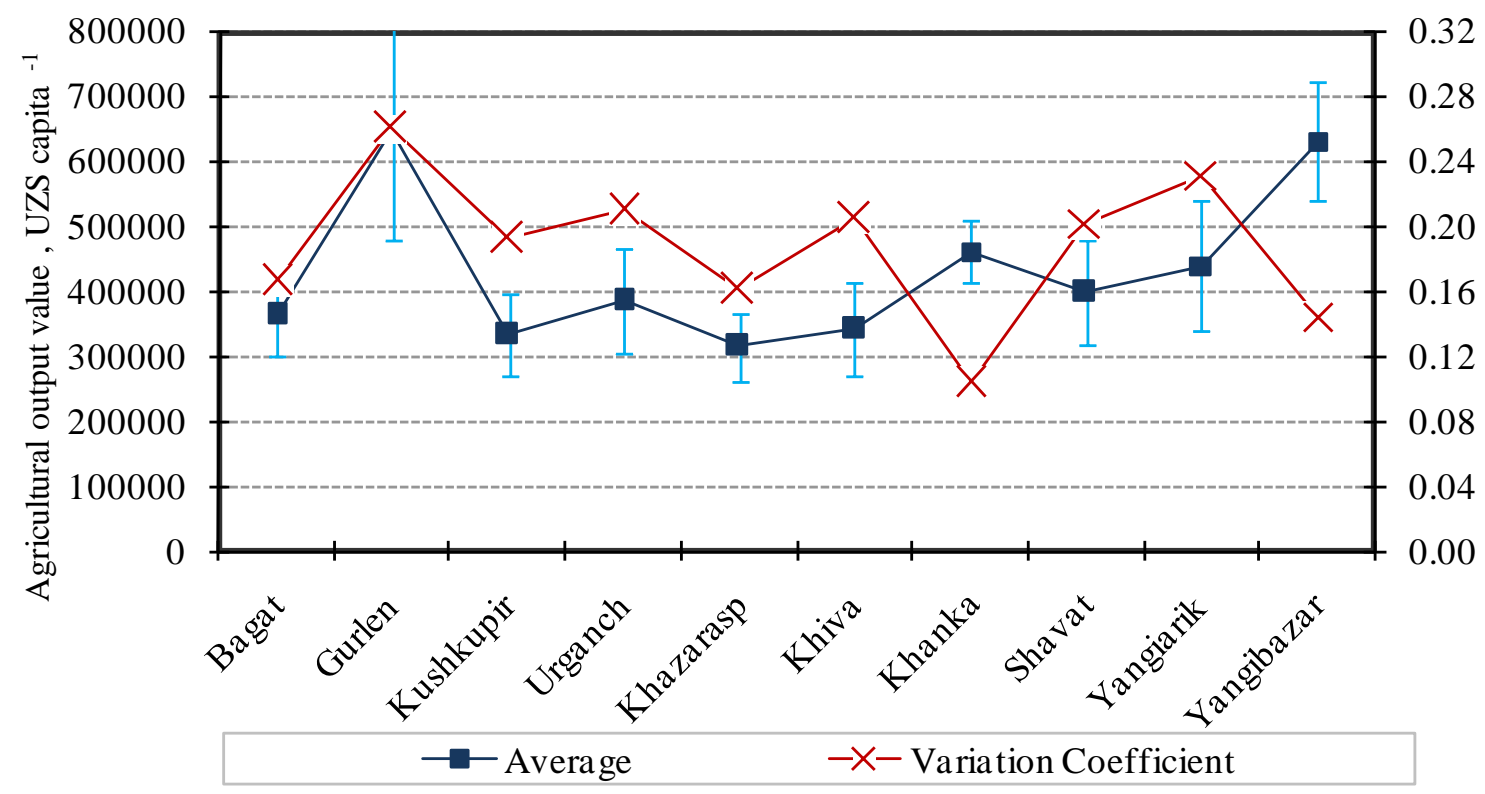


Due to differences in population and irrigated area per capita across districts, equity in resource distribution should also take population density into consideration.

\section{Summary and Conclusions}

Considering the importance of equal and efficient water distribution, this paper analyzes linkages between water access and per hectare, per cubic meter and per capita agricultural output value. Analyses were conducted for the case of the Khorezm region, where the rural livelihoods mainly rely on irrigated agriculture and thus, due to the agro-climatic conditions, on irrigation water availability.

According to assessments of agricultural output value per hectare, the districts with a lower level of land productivity have lower variability and vice versa. The analysis showed also the impact of factors other than water access such as soil quality, crop structure, and market access on the agricultural income level. However, in spite of this impact, average agricultural revenue per hectare was generally lower in water scarce years, and higher in water abundant years. Privatization reforms also partially impacted the increased trend of agricultural revenue per hectare over time.

Calculations on water use showed high uses per cropped area in the downstream districts of the Khorezm region, mainly due to high conveyance losses. One exception was the Shavat district, owing to its direct access to irrigation water from one of the three major channels in the region. In spite of its closeness to the Amu Darya River, Bagat district showed also high water consumption per hectare because of a high share of sandy and sandy loamy croplands. Water productivity was therefore correlated with temporal and spatial water availability, which calls for more efficient use of water resources particularly in downstream districts such as Kushkupir.

Agricultural revenue per capita was the lowest in Kushkupir due to the combined effect of low yields and restricted water access, while upstream districts such as Gurlen, Khazarasp, and Yangibazar seemed to be privileged by higher yields, sufficient water availability throughout all years and a lower population density.

The high differentiation of per capita agricultural revenue across the districts and over the years, and low water productivity at the tail end districts, particularly in water abundant years, underlined the drawbacks of the ill-managed technical, organizational and institutional structure in water resource distribution. This calls not only for the improvement of conveyance and field level water application efficiencies but, in addition, further market liberalization, improvements in market infrastructure and crop diversification to increase economic water productivity providing greater agricultural revenue. This study can be further developed using crop allocation optimization models, whose objective function maximizes income and minimizes income differentiation and water losses. Analyzing water availability impact on rural livelihoods using more detailed WUA level data would provide stronger incentives than those provided here.

\section{Acknowledgements}

The German Ministry for Education and Research (BMBF; project number 0339970A) funded this study. This paper includes research results made possible by the ZEF/UNESCO project entitled: Economic and Ecological Restructuring of Land and Water Use in the Khorezm Region (Uzbekistan): A Pilot Project in Development Research. We are especially thankful to Murod Sultanov from GIS 
Center in Urgench, Uzbekistan, for GIS based analyses and three anonymous referees for their valuable comments on an earlier version of this manuscript.

\section{References}

1. Wegerich, K. A critical review of the concept of equity to support water allocation at various scales in the Amudarya basin. Irrig. Drain. Syst. 2007, 21, 185-195.

2. Integrated Water Resources Management; TAC Background Papers No. 4; Global Water Partnership (GWP): Stockgolm, Sweden, 2000; Available online: http://www.gwptoolbox.org/ images/stories/gwplibrary/background/tac_4_english.pdf (accessed on 15 August 2010).

3. Abdullayev, I.; De Fraiture, Ch.; Giardano, M.; Yakubov, M.; Rasulov, A. Agricultural water use and trade in Uzbekistan: Situation and potential impacts of market liberalization. Water Resour. Dev. 2009, 1, 47-63.

4. Conrad, C.; Dech, S.W.; Hafeez, M.; Lamers, J.P.A.; Martuis, C.; Strunz, G. Mapping and assessing water use in a Central Asian irrigation system by utilizing MODIS remote sensing products. Irrig. Drain. Syst. 2007, 21, 197-218.

5. Martius, C.; Lamers, J.P.A.; Wehrheim, P.; Schoeller-Schletter, A.; Eshchanov, R.; Tupitsa, A.; Khamzina, A.; Akramkhanov, A.; Vlek, P.L.G. Developing Sustainable Land and Water Management for the Aral Sea Basin through An Interdisciplinary Research. In Water in Agriculture; ACIAR Proceedings No. 116; Seng, V., Craswell, E., Fukai, S., Eds.; Australian Center for International Agricultural Research (ACIAR): Canberra, Australia, 2004.

6. Bekchanov, M.; Lamers, J.P.A.; Martius, C. Pros and cons of adopting water-wise approaches in the lower reaches of the Amu Darya: A socio-economic view. Water 2010, 2, 200-216; Available online: http://www.mdpi.com/2073-4441/2/2/200/pdf (accessed on 1 July 2010).

7. Abdullayev, I.; Nurmetova, F.; Abdullaeva, F.; Lamers, J. Socio-technical Aspects of Water Management in Uzbekistan: Emerging Water Governance Issues at the Grass Root Level. In Central Asian Waters; Rahaman, M.M., Varis, O., Eds.; Helsinki University of Technology: Helsinki, Finland, 2008; pp. 89-103.

8. Müller, M. Where Has All the Water Gone? In Continuity and Change: Land and Water Use Reforms in Rural Uzbekistan; Wehrheim, P., Shoeller-Schletter, A., Martius, C., Eds.; Leibniz Institute of Agricultural Development in Central and Eastern Europe (IAMO): Haale, Germany, 2008; Volume 43, pp. 89-104.

9. Conrad, C. Fernerkundungsbasierte Modellierung und hydrologische Messungen zur Analyse und Bewertung der landwirtschaftlichen Wassernutzung in der Region Khorezm (Usbekistan). Ph.D. Thesis, Bonn University, Bonn, Germany, 6 December 2006.

10. Glazirin, G.E.; Chanishev, S.G.; Chub, V.E. Short Overview of Climate in Uzbekistan; Chinor ENK - Galaba: Tashkent, Uzbekistan, 1999; p.29.

11. Poverty and Food Insecurity in Uzbekistan; World Food Program (WFM): Rome, Italy, 2008; Available online: http://documents.wfp.org/stellent/groups/public/documents/ena/wfp179011.pdf (accessed on 15 July 2010).

12. Müller, M. A General Equilibrium Approach to Modeling Water and Land Use Reforms in Uzbekistan. Ph.D. Thesis, Bonn University, Bonn, Germany, 20 May 2006; pp. 15-44. 
13. Statistical Review-Socio-Economic Development Indicators for the Khorezm Region in the Years of 1991-2005; Regional Statistical Department of Khorezm (OblStat): Urgench, Uzbekistan, 2006.

14. Information on the Program of Attracting Foreign Investment to Khorezm Region; Ministry for Foreign Economic Relations, Investments and Trade of the Republic of Uzbekistan (MFER): Tashkent, Uzbekistan, 2008; Available online: http://www.mfer.uz (accessed on 10 June 2008).

15. Rudenko, I.; Grote, U.; Lamers, J.P.A. Using a Value Chain Approach for Economic and Environmental Impact Assessment of Cotton Production in Uzbekistan. In Proceedings of the NATO Advanced Research Workshop on Environmental Problems of Central Asia and Their Economic, Social and Security Impacts, Tashkent, Uzbekistan, 2007; Qi, J., Evered, T., Eds.; Springer: Dordrecht, The Netherlands, 2007; pp. 361-380; Available online: http://www.springer.com/environment/environmental+management/book/978-1-4020-8958-9 (accessed on 20 December 2009).

16. Khorezm Regional Department of Statistics. Agricultural Indicators for Khorezm Oblast, 2000-2007; OblStat: Urgench, Uzbekistan, 2006.

17. FAOSTAT. Database; Food and Agriculture Organization (FAO): Rome, Italy, 2008; Available online: http://faostat.fao.org/site/567/DesktopDefault.aspx?PageID=567\#ancor (accessed on 10 October 2008).

18. Dixon, J.; Gulliver, A.; Gibbon, D. Farming Systems and Poverty: Improving Farmer's Livelihoods in a Changing World; FAO and World Bank: Rome, Italy, 2001.

19. Special Report on FAO/WFP Crop and Food Supply Assessment Mission to the Karakalpakstan and Khorezm Regions of Uzbekistan; FAO: Rome, Italy, 2000.

20. Djanibekov, N. A Micro-Economic Analysis of Farm Restructuring in the Khorezm Region (Uzbekistan). Ph.D. Thesis, Bonn University, Bonn, Germany, 15 May 2008.

21. Veldwisch, G.J.A. Cotton, Rice \& Water: The Transformation of Agrarian Relations, Irrigation Technology and Water Distribution in Khorezm, Uzbekistan. Ph.D. Thesis, Bonn University, Bonn, Germany, 2 June 2008.

22. Bobojonov, I. Modeling Crop and Water Allocation under Uncertainty in Irrigated Agriculture: A Case Study on the Khorezm Region, Uzbekistan. Ph.D. Thesis, Bonn University, Bonn, Germany, 12 December 2008.

23. Molden, D. Accounting for Water Use and Productivity; SystemWide Initiative for Water Management (SWIM) Paper 1; International Water Management Institute (IWMI): Colombo, Sri Lanka, 1997.

24. Abdullayev, I.; Molden, D. Spatial and temporal variability of water productivity in the Syr Darya Basin, Central Asia. Water Resour. Res. 2004, 40, doi:10.1029/2003WR002364.

(C) 2010 by the authors; licensee MDPI, Basel, Switzerland. This article is an open access article distributed under the terms and conditions of the Creative Commons Attribution license (http://creativecommons.org/licenses/by/3.0/). 